\title{
INFORMATYKA EKONOMICZNA
}

BUSINESS INFORMATICS

$4(54) \cdot 2019$ 


\section{SCIENTIFIC COUNCIL}

Frederic Andres (National Institute of Informatics, Japan)

Dimitar Christozov (American University in Bulgaria, Bulgaria)

Jerzy Gołuchowski (University of Economics in Katowice, Poland)

André Ludwig (Kühne Logistics University, Hamburg, Germany)

Eunika Mercier-Laurent (Jean Moulin - Lyon 3 University, France)

Małgorzata Nycz-Łukaszewska (Wrocław University of Economics, Poland)

Peter Stanchev (Kettering University, Flint, Michigan, United States)

Rainer Unland (Institut für Informatik und Wirtschaftsinformatik (ICB),

Essen, Germany)

Jan Vanthienen (Université Catholique de Louvain, Belgium)

\section{EDITORIAL COMMITTEE}

Małgorzata Nycz-Łukaszewska - Editor-in-Chief

Andrzej Bąk

Andrzej Bytniewski

Helena Dudycz

Bogdan Franczyk

Leszek Maciaszek

Mieczysław L. Owoc

Kazimierz Perechuda

Iwona Chomiak-Orsa - Managing Editor

iwona.chomiak@ue.wroc.pl

+48713680323

SUBJECT EDITOR

Iwona Chomiak-Orsa 


\section{INFORMATYKA EKONOMICZNA}

\section{BUSINESS INFORMATICS}

$4(54) \cdot 2019$

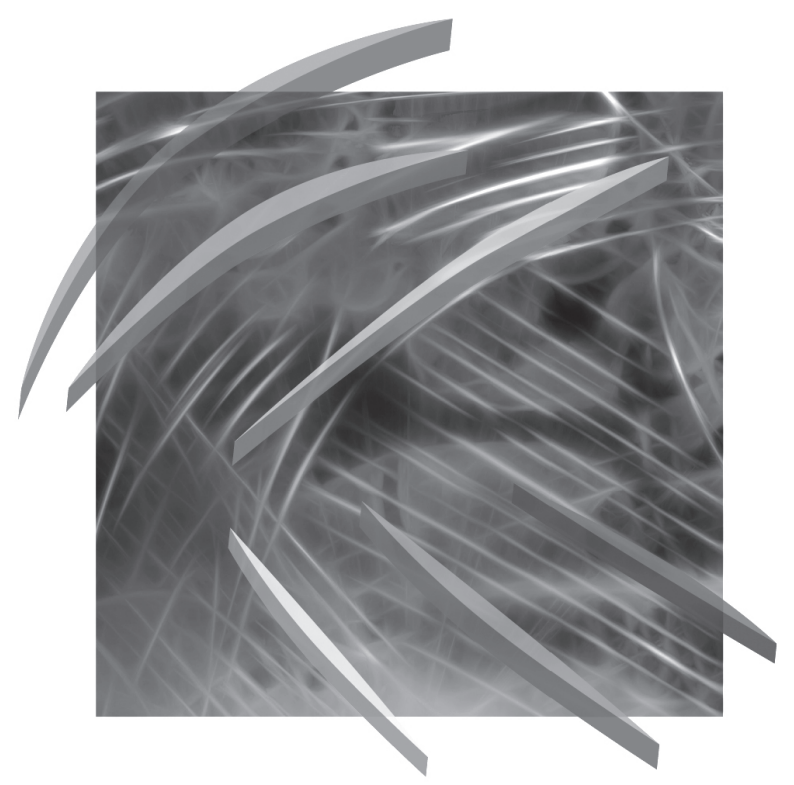

VIE Publishing House of Wroclaw University of Economics and Business Wroclaw 2019 
Copy-editing: Elżbieta Macauley, Tim Macauley, Aleksandra Śliwka

Layout: Barbara Łopusiewicz

Proof-reading: Rafał Galos

Typesetting: Beata Mazur

Cover design: Beata Dębska

Information on submitting and reviewing papers is available on websites www.wydawnictwo.ue.wroc.pl

www.businessinformatics.ue.wroc.pl

This work is licensed under the Creative Commons Attribution-ShareAlike 4.0 International License.

To view a copy of this license, visit http://creativecommons.org/licenses/by-sa/4.0/

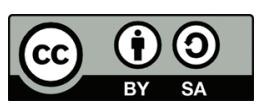

ISSN 1507-3858

e-ISSN 2450-0003

The original version: printed

Publication may be ordered in Publishing House:

Wydawnictwo Uniwersytetu Ekonomicznego we Wrocławiu

ul. Komandorska 118/120, 53-345 Wrocław

tel.7136-80-602; e-mail: econbook@ue.wroc.pl

www.ksiegarnia.ue.wroc.pl

Printing: TOTEM 


\section{Contents}

Preface

Iwona Chomiak, Katarzyna Golusińska, Jakub Kruczek, Maciej Krajewski: ICT solutions in Polish law firms / Narzędzia informacyjno-komunikacyjne wykorzystywane w polskich kancelariach prawnych .....

Anna Karmańska: Business Intelligence in consolidation of financial statements / Business Intelligence w konsolidacji sprawozdań finansowych.....

Lukasz Lysik, Karol Lopaciński: Use of virtual reality in digital marketing communication/Wykorzystanie wirtualnej rzeczywistości w cyfrowej komunikacji marketingowej

neta Nejman, Joanna Sadłowska-Wrzesińska: The use of information and communication technologies in the process of introducing incentive schemes / Wykorzystanie technologii informacyjno-komunikacyjnych $\mathrm{w}$ procesach wdrażania systemów motywacyjnych

Gracja Niesler, Andrzej Niesler: Methodological apparatus and instruments for personalization in adaptive tutoring systems/Adaptacyjny system wspomagania nauczania: aparat metodologiczny oraz narzędzia personalizacji. ....

Arkadiusz Wierzbic, Karol Szewczyk: Digitalization of audit actions in the Industry 4.0 era / Cyfryzacja działań auditowych w dobie przemysłu $4.0 \ldots$

Radoslaw Wójtowicz: The basics of requirements analysis in the methodology of ECM systems implementation/Podstawy analizy wymagań w metodyce implementacji systemów ECM 



\section{Preface}

The subject of the development and implementation of ICT is a source of many scientific considerations, whereas investing in modern ICT solutions is one of the main directions of organizational improvement. Therefore, the subject of management systems is still current and an important topic of publication. The editors would like to thank the authors for the following articles, thanks to which the magazine is thriving and developing.

An extremely valuable feature of the Business Informatics series is the fact that the studies included in it present various opinions and points of view on the application of modern ICT solutions. The perspectives and views presented by the authors allow the readers to broaden their own reflections related to the created view on the possibilities and directions of the application of information and communication technologies in economic practice. It is also important that not all the articles sent for publication meet the formal and substantive requirements. This further increases the significance and value of the texts which have received double positive reviews and were then selected for publication in this issue of Business Informatics. Currently, as a result of a multistage and strict formal and substantive verification of our journal, approximately $25 \%$ of the texts submitted are accepted for publication.

The editor of this issue would like to express his gratitude to all the authors who wanted to share their experiences and opinions. He would also like to thank the reviewers for their insightful and factual assessments of the submitted works. 